\title{
PENGARUH TEMPAT TERHADAP KEPUTUSAN PEMBELIAN KAIN TENUN IKAT SIKKA
}

\author{
Nur Chotimah $^{1}$, Yosefa Veronika Ansila ${ }^{2 *}$, Muhammad Syarun ${ }^{3}$ \\ 1,2,3 Institut Keguruan dan Ilmu Pendidikan Muhammadiyah Maumere \\ Jl. Jenderal Sudirman Kel. Waioti - Kec. Alok Timur, Maumere - Kab. Sikka - Provinsi Nusa Tenggara Timur 86118 \\ *Penulis Korespondensi; Email: nur.chotimah329@gmail.com ${ }^{1}$, ansilaveronika@gmail.com², torighgifari@gmail.com ${ }^{3}$
}

\begin{abstract}
Abstrak
Tenun ikat merupakan kain tenun tradisional asli Nusa Tenggara Timur. Kain tenun ikat dibuat dari proses menenun oleh tangan masyarakat Sikka sendiri. Di era moderen sekarang pesona Kain Tenun Ikat Sikka tak tergerus zaman lantaran masih produksi hingga kini. Penelitian ini bertujuan untuk menemukan pengaruh Tempat terhadap Keputusan Pembelian Kain Tenun Ikat Sikka pada tahun 2021. Populasi penelitian ini adalah seluruh konsumen yang pernah membeli Kain Tenun Ikat Sikka. Sampel dalam penelitian ini berjumlah 96 orang. Teknik sampling yang digunakan adalah teknik random sampling dengan istilah pengambilan sampel secara acak. Penelitian ini menggunakan metode penelitian kuantitatif. Semua pernyataan valid reliabel, normal, linear dan non heteroskedastisitas. Berdasarkan hasil penelitian yang telah teruji menunjukkan terdapat pengaruh positif dan signifikan varibel Tempat terhadap Keputusan Pembelian Kain Tenun Ikat Sikka.

Kata Kunci: Tempat, keputusan pembelian, Kain Tenun Ikat Sikka.

Abstract

Tenun ikat is a traditional woven fabric native to East Nusa Tenggara. Tenun ikat is made from the weaving process by the hands of the Sikka people themselves. In the modern era, the charm of Tenun Ikat Sikka has not been eroded by time because it is still being produced until now. This study aimed to find the influence on purchase decisions for Tenun Ikat Sikka in 2021. The population of this research was all consumers who had purchased Tenun Ikat Sikka. The sample in this study found 96 people. The sampling technique used was a random sampling technique with random sampling. This study used quantitative research methods. All valid statements were reliable, normal, linear, and non-heteroscedastic. Based on research that had been tested, it proved that there was a positive and significant effect on the place variable on the purchasing decision of Tenun Ikat Sikka.
\end{abstract}

Keywords: Place, purchase decision, Tenun Ikat Sikka.

\section{Pendahuluan}

Keputusan pembelian merupakan suatu konsep dalam perilaku pembelian yang mana konsumen memutuskan untuk bertindak atau melakukan sesuatu dan dalam hal ini melakukan pembelian ataupun memanfaatkan produk atau jasa tertentu (Balawera, 2013). Pengambilan keputusan konsumen pada dasarnya merupakan proses pemecahan masalah. Peneliti menggunakan variabel Keputusan Pembelian ini karena studi tentang keputusan pembelian masih layak untuk diteliti mengingat semakin banyaknya produk yang beredar mengakibatkan perlunya berbagai pertimbangan bagi masyarakat dalam melakukan keputusan pembelian.

Suatu produk hendaknya memiliki rangsangan terhadap konsumen. Menurut Andika dan Susanti (2016), secara umum bauran pemasaran menekankan pada pengertian suatu strategi yang mengintegrasikan product, price, promotion dan place yang mana kesemuanya itu diarahkan untuk dapat menghasilkan omset penjualan yang maksimal atas produk yang dipasarkan dengan memberikan kepuasan pada para pelanggan.

Dari ke empat marketing mix di atas salah satu faktor yang memengaruhi keputusan pembelian adalah faktor tempat. Menurut Wariki, Mananeke, dan Tawas (2015), pemilihan tempat usaha yang tepat akan menentukan keberhasilan usaha tersebut di masa yang akan datang. Penentuan tempat dalam suatu bisnis memiliki peran penting, karena tempat yang strategis akan menarik para pengujung dalam melakukan keputusan 
pembelian. Hal ini menunjukkan bahwa tempat merupakan letak atau toko pengecer pada daerah yang strategis, sehingga dapat memaksimumkan laba (Mundir, 2015). Penentuan tempat dalam suatu bisnis memiliki peran penting, karena tempat yang strategis akan menarik para pengujung dalam melakukan keputusan pembelian. Para pengujung dapat mampir dan melihat jualan yang telah ditawarkan karena tempat yang dapat mudah dijangkau. Penentuan tempat akan memengaruhi dua hal, yaitu jangkauan penjualan dan biaya.

Tenun Ikat Sikka merupakan salah satu warisan kebudayaan leluhur masyarakat di Sikka. Kain tenun ikat adalah kerajinan tangan yang memiliki daya jual yang tinggi. Kain tenun ikat sendiri di Sikka memiliki motif, ragam, ciri khas dan juga memiliki makna simbolik yang berbeda-beda.

Kain tenun ikat tradisional ini merupakan karya seni dan identitas dari masyarakat di Sikka yang memiliki daya pikat yang sangat kuat serta layak untuk dikembangkan serta dilestarikan (Octaviani \& Komalasari, 2020). Kain tenun ikat ini sendiri biasanya dibuat oleh kaum wanita. Sesuai dengan data jumlah kelompok tenun ikat di Kabupaten Sikka pada tahun 2017 adalah 121 kelompok dengan 2.111 orang anggota, dari data ini menunjukkan bahwa terdapat sekitar 1,6\% pengrajin tenun ikat (Sina \& Tefa, 2019). Kain Tenun Ikat Sikka yang dihasilkan ditawarkan dan dijual kepada masyarakat secara umum dan dibeli oleh konsumen sesuai dengan kebutuhan masyarakat. Dengan banyaknya corak dan motif kain tenun ikat yang berbeda maka dapat memengaruhi keputusan pembelian oleh konsumen.

Berdasarkan latar belakang, maka yang menjadi rumusan masalah dalam penelitian ini adalah apakah variabel Tempat berpengaruh terhadap Keputusan Pembelian Kain Tenun Ikat Sikka? Tujuan penelitian ini adalah untuk mengetahui pengaruh variabel Tempat terhadap keputusan pembelian Kain Tenun Ikat Sikka.

\section{Kajian Teoritis dan Hipotesis}

Tempat

Menurut Afrina (2017), lokasi usaha dapat disebut dengan saluran distribusi perusahaan karena lokasi juga berhubungan langsung dengan pembeli atau konsumen atau dengan kata lain lokasi juga merupakan tempat produsen menyalurkan produknya kepada konsumen. Menurut Tendean, Mananeke, dan Ferdy (2020), tempat adalah keputusan yang dibuat perusahaan atau instansi pendidikan berkaitan dengan yang mana operasi dan stafnya akan ditempatkan. Dapat disimpulkan bahwa, tempat adalah suatu keputusan perusahaan untuk menentukan tempat usaha, menjalankan kegiatan usaha atau kegiatan operasional, dan mendistribusikan barang atau jasa yang menjadi kegiatan bisnisnya kepada konsumen. Pentingnya tempat bagi perusahaan atau pengusaha sangat memengaruhi keputusan sasaran pasar dalam menentukan keputusan pembeliannya.

\section{Keputusan Pembelian}

Keputusan pembelian merupakan tahap dalam proses pengambilan keputusan pembelian, yang mana konsumen dalam proses pemikiran membentuk kumpulan pilihan atas merek-merek suatu produk yang ada, kemudian menjatuhkan pilihan atas apa yang disukai dan benar-benar membeli produk (Maharani, 2015). Adapun tahap pengambilan keputusan pembelian yaitu pengenalan kebutuhan, pencarian informasi, evaluasi alternatif, keputusan pembelian, dan perilaku pasca pembelian

\section{Tenun Ikat}

Kain tenun ikat merupakan salah satu produk kerajinan tangan yang menjadi ciri khas dari wilayah Sikka dan menjadi warisan budaya dari Sikka. Hal ini tercermin dari motif dan corak yang ada pada Kain Tenun Ikat Sikka yang di dalamnya terkandung nilai-nilai khusus. Tenun ikat adalah kain yang ditenun dari helaian benang pakan (benang dalam posisi melintang) dan benang lungsi (benang dalam posisi membujur) yang sebelumnya diikat dan di celupkan ke dalam zat pewarna alami (Octaviani \& Komalasari, 2020). Kain Tenun Ikat Sikka adalah salah satu dari sekian banyak produk budaya tradisional khas Indonesia yang dibuat secara tradisional namun bernilai seni tinggi dan indah. Pembuatan kain tenun ikat melalui proses yang sangat lama dan dibutuhkan keahlian ksusus dari pembuatnya.

\section{Pengaruh Tempat terhadap Keputusan Pembelian Kain Tenun Ikat di Kabupaten Sikka}

Adapun hipotesis yang diajukan adalah:

$H_{0}$ : Tidak terdapat pengaruh Tempat terhadap Keputusan Pembelian kain Tenun Ikat Sikka.

$H_{l}$ : Terdapat pengaruh Tempat terhadap Keputusan Pembelian Kain Tenun Ikat Sikka. 


\section{Model Penelitian}

Penelitian ini membahas mengenai pengaruh Tempat terhadap Keputusan Pembelian Kain Tenun Ikat Sikka. Berdasarkan kajian literatur dan penelitian empiris terdahulu, maka model penelitian dapat dilihat pada Gambar 1.

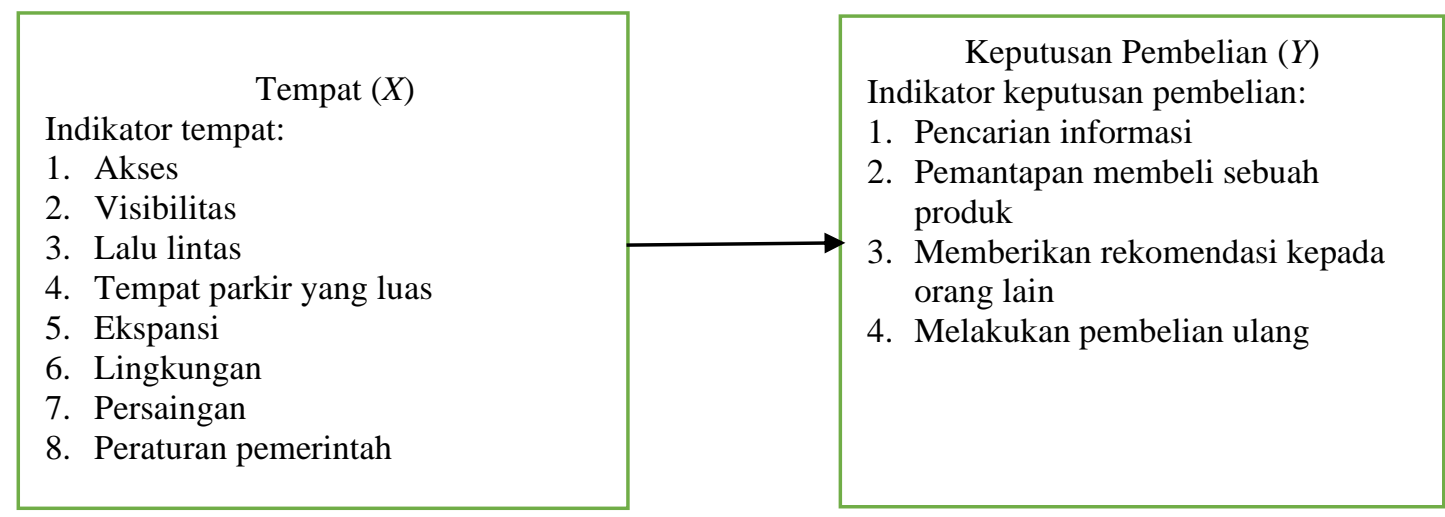

\section{Gambar 1. Model penelitian}

\section{Metode Penelitian}

Metode penelitian yang digunakan dalam penelitian ini adalah penelitian Kuantitatif yang merupakan salah satu jenis penelitian yang spesifikasinya adalah sistematis, terencana, dan terstruktur dari sejak awal hingga pembuatan desain penelitiannya (Afrina, 2017).

Teknik penentuan sampel dalam penelitian ini mengambil sampel secara acak terhadap konsumen yang pernah melakukan pembelian terhadap produk tenun ikat di Mamumere. Jadi calon responden hendaknya memiliki kriteria sebagai konsumen tenun ikat Maumere yang berada di pasar. Teknik dalam pengambilan sampel ini ialah Random Sampling yaitu teknik pengambilan sampel yang mana semua individu dalam populasi baik secara sendiri-sendiri atau bersama-sama diberi kesempatan yang sama untuk dipilih sebagai anggota sampel menurut (Noviyanti, 2018), sesuai dengan namanya maka sampel yang diambil dilakukan secara acak. Hal ini dikarenakan jumlah populasi tidak teridentifikasi dengan pasti. Jumlah responden yang digunakan dalam penelitian ini sebanyak 96 responden dengan menyebarkan kuesioner penelitian kepada konsumen pengguna kain tenun ikat. Angket terdiri atas 20 pernyataan untuk variabel Tempat $(X)$ dan 13 pernyataan untuk variabel Keputusan Pembelian $(Y)$. Kuesioner yang terkumpul diolah menggunakan SPSS 25.0.

\section{Analisis Data dan Pembahasan}

Jumlah responden pada penelitian ini sebanyak 96 orang. Berdasarkan Tabel 1 diketahui bahwa mayoritas responden adalah berjenis kelamin wanita yaitu dengan jumlah responden 79 orang dengan persentase 82,3\% dari seluruh responden, sedangkan untuk sisanya yaitu 17 orang responden adalah berjenis kelamin perempuan sebesar $17,7 \%$.

Pada penelitian ini jumlah responden sebanyak 96 orang terdiri atas $12,5 \%$ berusia antara $<20$ tahun dengan jumlah responden 12 orang, 37,5\% berusia antara 20-30 tahun dengan jumlah 36 responden, 19,8\% berusia 30-40 tahun dengan jumlah 19 responden, dan 30,2\% berusia $>40$ tahun dengan jumlah 29 responden. Pada penelitian ini jumlah responden sebanyak 96 orang terdiri atas 22 responden pelajar/mahasiswa, 15 responden PNS, 32 responden ibu rumah tangga, dan 27 responden lainnya.

\section{Tabel 1}

Karakteristik Responden

\begin{tabular}{cccc}
\hline & & Jumlah Responden & Persentase \\
\hline Jenis Kelamin & Pria & 17 & $17,7 \%$ \\
Usia & Wanita & 79 & $82,3 \%$ \\
& $<20$ tahun & 12 & $12,5 \%$ \\
& $20-30$ tahun & 36 & $37,5 \%$ \\
& $30-40$ tahun & 19 & $19,8 \%$ \\
\multirow{3}{*}{ Pekerjaan } & $>40$ tahun & 29 & $30,2 \%$ \\
& Pelajar/Mahasiswa & 22 & $22,9 \%$ \\
& PNS & 15 & $15,6 \%$ \\
& Ibu Rumah Tangga & 32 & $33,3 \%$ \\
& Lainnya & 27 & $28,1 \%$ \\
\hline
\end{tabular}


Tabel 2

Uji Normalitas

\begin{tabular}{cc}
\hline Signifikansi & Keterangan \\
\hline 0,200 & Normal \\
\hline
\end{tabular}

Berdasarkan hasil uji normalitas Kolmogorov-Smirnov di Tabel 2 menunjukkan bahwa nilai signifikansi $0,200>0,05$, maka data berdistribusi secara normal.

Tabel 3

Uji Linearitas

\begin{tabular}{ccc}
\hline Variabel & Sig $($ F-Linearity $)$ & Keterangan \\
\hline Tempat & 0,002 & Linear \\
\hline
\end{tabular}

Berdasarkan Tabel 3 diketahui nilai signifikansi Tempat sebesar 0,002. Nilai tersebut lebih kecil dari 0,05 , sehingga dapat disimpulkan terdapat hubungan linier secara signifikan antara variabel Tempat terhadap Keputusan Pembelian.

Tabel 4

Uji Heterokedasitas

\begin{tabular}{ccc}
\hline Variabel & Sig. & Keterangan \\
\hline Tempat & 0,096 & Non heterokedasitas \\
\hline
\end{tabular}

Hasil uji ini dapat diketahui dengan mengetahui nilai signifikansinya, apabila >0,05, maka dapat disimpulkan bahwa tidak terjadi heterokedasitas.

\section{Tabel 5}

Analisis Regresi Linear Sederhana

\begin{tabular}{ccc}
\hline Variabel & Konstanta & Koefisien \\
\hline Tempat & 38,090 & 0,228 \\
\hline
\end{tabular}

Berdasarkan analisis data dengan menggunakan program IBM SPSS Statistics 25, diketahui nilai constant (a) sebesar 38,090 sedangkan nilai Tempat ( $b /$ koefisien regresi) sebesar 0,228, sehingga persamaan regresinya dapat ditulis:

$Y=38,090+0,228(X)$

Keputusan Pembelian $=38,090+0,228$ Tempat

Berdasarkan persamaan regresi linear sederhana di atas konstanta sebesar 38.090 mengandung arti bahwa nilai konsisten variabel Keputusan Pembelian adalah sebesar 38.090. Koefisien regresi Tempat $(X)$ sebesar 0,228 menyatakan bahwa setiap peningkatan pada Tempat sebesar satu satuan, maka Keputusan Pembelian akan mengalami penurunan sebesar 0,228 satuan. Koefisien regresi linear sederhana bernilai positif, sehingga dapat dikatakan bahwa arah pengaruh variabel Tempat $(X)$ terhadap variabel Keputusan Pembelian $(Y)$ adalah positif.

\section{Tabel 6}

$\underline{\mathrm{Uji} t}$

\begin{tabular}{ccccc}
\hline Variabel & $t_{\text {hitumg }}$ & $t_{\text {tabel }}$ & Sig. & Keterangan \\
\hline Tempat & 3,332 & 1,985 & 0.001 & Terdapat pengaruh \\
\hline
\end{tabular}

Berdasarkan hasil uji $t$ dengan menggunakan program IBM SPSS Statistic 25, diperoleh nilai $t_{\text {hitumg }}$ sebesar $3.332>$ dari $t_{\text {tabel }} 1,985$ dan nilai signifikasi sebesar 0,001 pada tingkat signifikasi 0,05. Karena 0,001<0,05, maka $H_{0}$ ditolak dan $H_{l}$ diterima.

$H_{0}$ : Tidak terdapat Pengaruh antara Tempat $(X)$ terhadap Keputusan Pembelian $(Y)$ Kain tenun ikat Sikka.

$H_{l}$ : Terdapat Pengaruh antara Tempat $(X)$ terhadap Keputusan Pembelian $(Y)$ Kain tenun ikat Sikka. 
Tabel 7

Hasil Uji Koefisien Determinasi

\begin{tabular}{ccccc}
\hline Variabel & $R$ & $R$ Square & Adjusted $R$ Square & Std. Error of the Estimate \\
\hline Tempat & $0,325^{a}$ & 0,106 & 0,096 & 4,208 \\
\hline
\end{tabular}

Berdasarkan Tabel 7 diperoleh besarnya koefisien determinasi (Adjusted $R$ Square) yang diperoleh sebesar 0,096. Ini berarti 9,6\% Keputusan Pembelian dipengaruhi oleh Tempat, sedangkan sisanya yaitu 90,4\% dipengaruhi oleh variabel lain yang tidak diteliti.

\section{Pembahasan}

Hasil penelitian ini menunjukkan bahwa variabel Tempat $(X)$ berpengaruh positif dan signifikan terhadap variabel Keputusan Pembelian $(Y)$ Kain Tenun Ikat Sikka, dibuktikan dengan hasil uji $t$ diperoleh nilai $t_{\text {hitung }}$ sebesar $3.332>t_{\text {tabel }} 1,985$ dan nilai signifikansi sebesar 0,001 pada tingkat signifikansi 0,05, maka $H_{0}$ ditolak dan $H_{l}$ diterima. Berdasarkan hasil analisis $R$ square atau koefisien determinasi variabel Tempat $(X)$ terhadap variabel Keputusan Pembelian $(Y)$ sebesar 0,096 yang menunjukkan bahwa variabel Tempat $(X)$ memiliki kontribusi pengaruh terhadap variabel Keputusan Pembelian $(Y)$ sebesar 9,6\%, sedangkan sisanya dipengaruhi oleh variabel lain yang tidak diteliti.

Berdasarkan Hasil analisis deskriptif pada setiap indikator untuk variabel Tempat $(X)$ Kain Tenun Ikat Sikka dalam penelitian ini diperoleh kriteria berada pada rentangan cukup, tinggi dan sanggat tinggi. Pada varibel Tempat $(X)$ pada indikator akses diperoleh kriteria rentangan sangat tinggi $(86 \%)$, indikator visibilitas diperoleh rentangan sangat tinggi (83\%), indikator lalu lintas diperoleh kriteria rentangan sangat tinggi (81\%), indikator tempat parkir diperoleh kriteria rentangan tinggi (79\%), Indikator ekspansi diperoleh kriteria rentangan sangat tinggi (82\%), indikator lingkungan diperoleh kriteria rentangan sangat tinggi (85\%), indikator persaingan diperoleh kriteria rentangan tinggi (72\%), indikator peraturan pemerintah diperoleh kriteria rentangan cukup (54\%). Dan pada variabel Keputusan Pembelian (Y) Kain Tenun Ikat Sikka analisis deskriptif berada pada kriteria sanggat tinggi yakni pada indikator pencarian informasi diperoleh kriteria rentangan sangat tinggi (87\%), indikator pemantapan membeli sebuah produk diperoleh kriteria rentangan sangat tinggi (90\%), indikator memberikan rekomendasi kepada orang lain diperoleh kriteria rentangan sangat tinggi (82\%), dan indikator melakukan pembelian ulang diperoleh kriteria rentangan sangat tinggi (85\%). Sesuai dengan hasil analisis deskriptif setiap indikator diatas bahwa hasil penelitian memberikan indikasi terhadap tempat dengan mendapatkan respon yang baik. Artinya, tempat mendapatkan respon yang positif terhadap keputusan untuk melakukan pembelian Kain Tenun Ikat Sikka.

Hasil penelitian ini sejalan dengan penelitian yang dilakukan oleh Larosa dan Sugiarto (2011) yang menyatakan bahwa lokasi berpengaruh positif dan signifikan terhadap keputusan pembelian, begitupun penelitian Ghanimata dan Kamal (2012) menyatakan bahwa Lokasi mempunyai pengaruh positif dan signifikan terhadap Keputusan Pembelian. Garatu (2013) dalam penelitiannya menyatakan bahwa Lokasi berpengaruh signifikan terhadap Keputusan Pembelian . Sukotjo dan Sumanto (2010) dalam hasil penelitian menyatakan bahwa variabel bebas yang berpengaruh signifikan terhadap Keputusan Pembelian adalah variabel Lokasi.

Tempat penjualan kain tenun ikat di Kabupaten Sikka letaknya strategis, hal itu dibuktikan dengan adanya beberapa faktor seperti banyaknya alternatif jalan, dan terdapat di pinggir jalan yang memudahkan konsumen menemukan tempat penjualan Kain Tenun Ikat Sikka. Penelitian ini sejalan dengan teori yang dikemukakan oleh parah ahli bahwa terdapat pengaruh positif dan signifikan variabel Tempat $(X)$ terhadap variabel Keputusan Pembelian $(Y)$ Kain Tenun Ikat Sikka. Hal ini menunjukkan bahwa tempat merupakan letak atau toko pengecer pada daerah yang strategis sehingga dapat memaksimumkan laba (Mundir, 2015). Tempat mengacu pada berbagai aktivitas pemasaran yang berusaha memperlancar dan mempermudah penyampaian atau penyaluran barang dan jasa dari produsen kepada konsumen (Fauji \& Faddila, 2020). Tempat penjualan kain tenun ikat juga sangat penting dilakukan dengan mempertimbangkan beberapa indikator antara lain akses, visibilitas, lalu lintas (traffic), tempat parkir, ekspansi, lingkungan, persaingan (lokasi pesaing), dan peraturan pemerintah (Fauji \& Faddila, 2020).

\section{Simpulan, Keterbatasan, dan Saran}

Berdasarkan hasil analisis penelitian yang telah dijelaskan sebelumnya, maka dapat disimpulkan bahwa variabel Tempat $(X)$ berpengaruh positif dan signifikan terhadap variabel Keputusan Pembelian $(Y)$ Kain Tenun Ikat Sikka. Hal ini dibuktikan dengan nilai $t_{\text {hitung }}$ sebesar $3.332>t_{\text {tabel }} 1,985$ dan nilai signifikansi sebesar 0,001 
pada tingkat signifikansi 0,05, maka disimpulkan $H_{0}$ ditolak dan $H_{l}$ diterima. Berdasarkan hasil analisis $R$ square atau Koefisien Determinasi varibel Tempat $(X)$ terhadap variabel Keputusan Pembelian $(Y)$ sebesar 0,096 yang menunjukkan bahwa variabel Tempat memiliki kontribusi pengaruh terhadap Keputusan Pembelian sebesar 9,6\% sedangkan sisanya dipengaruhi oleh variabel lain yang tidak diteliti.

\section{Keterbatasan}

Keterbatasan pada penelitian ini adalah tempat, dalam penelitian ini hanya ada satu tempat yang sudah diteliti oleh peneliti. Selain dari itu masih ada banyak tempat atau pasar yang belum diteliti, sehingga perlu dilakukan penelitian di tempat lain, untuk melihat keadaan tempat penjualan Kain Tenun Ikat Sikka yang belum pernah diteliti oleh peneliti.

\section{Saran}

Bagi tempat penjualan Kain Tenun Ikat Sikka hendaknya lebih meningkatkan strategi pemasaran langsung dan penjualan tatap muka yang tepat guna meningkatkan image atau citra pasar agar dapat menarik lebih banyak lagi pengunjung atau konsumen. Berkaitan dengan tempat, proses yang paling berpengaruh terhadap keputusan pembelian adalah memilih tempat atau pasar yang mampu mempertahankan aspek dan mampu menarik minat pembeli atau konsumen.

\section{Referensi}

Afrina, M. (2017). Analisa pengaruh produk, lokasi dan promosi terhadap keputusan pembelian nasabah Bank Syariah Bukopin. Diakses dari http://repository.uinjkt.ac.id/dspace/handle/1234 56789/41008

Andika, A., \& Susanti, F. (2016). Pengaruh marketing mix terhadap keputusan pembelian parfum di Azzwars Parfum Lubeg Padang. Diakses dari 10.31227/osf.io/upgc3

Balawera, A. (2013). Green marketing dan corporate social responsibility pengaruhnya terhadap keputusan pembelian konsumen melalui minat membeli produk organik di Freshmart kota Manado. Jurnal EMBA, 1(4), 2117-2129

Fauji, R., \& Faddila, S. P. (2020). Pengaruh kualitas pelayanan dan lokasi terhadap keputusan pembelian pada Johar Futsal Karawang. KREATIF: Jurnal Manajemen \& Bisnis Kreatif, 5(2), 35-65. https://doi.org/ 10.36805/manajemen.v5i2.1029

Garatu, T. (2013). Pengaruh pelayanan, harga dan lokasi terhadap keputusan pembelian pada Toko Ramayana Motor Poso Sulawesi Tengah. Jurnal Ilmiah EKOMEN, 13(1), $27-41$.

Ghanimata, F., \& Kamal, M. (2012). Analisis pengaruh harga, kualitas produk, dan lokasi terhadap keputusan pembelian (Studi pada pembeli produk Bandeng Juwana Elrina Semarang), Diponegoro Journal of Management, 1(4), 13-22.

Maharani, N. (2015). Proses pengambilan keputusan pembelian konsumen terhadap produk Iphone di Bandung. Jurnal Manajemen dan Bisnis (Performa), 12(1), 59-75. https://doi.org/10.29313/ performa.v0i1.3043

Wariki M. G., Mananeke, L., \& Tawas, H. (2015). The effect of the promotional mix, price perception and location of the purchasing decision and customer satisfaction on Tamansari Metropolitan Housing Manado. Jurnal EMBA, 3(2), 1073-1085.

Mundir (2015). Analisis pengaruh harga, lokasi dan kualitas pelayanan terhadap keputusan pembelian (Studi kasus pada Toko Mitra Nelayan Tanara Serang Banten). Diakses dari http://repository. uinjkt.ac.id/dspace/ handle/123456789/33169

Noviyanti, I. (2018). Pengaruh kualitas produkdan kualitas pelayanan terhadap kepuasan pelanggan pada CV Usaha Mandiri Jakarta Selatan. Jurnal Ilmiah Manajemen Forkamma, 1(2), 21-32. http://dx.doi.org/ 10.32493/frkm.v1i2.2538

Octaviani, L. K., \& Komalasari, A. S. (2020). Kain tenun ikat sebagai wisata budaya Kabupaten Sikka. Kepariwisataan: Jurnal Ilmiah, 14(3), 151-159.

Larosa, S. R., \& Sugiarto, Y. (2011). Analisis pengaruh harga, kualitas produk, dan lokasi terhadap keputusan pembelian (Studi kasus pada warung-warung makan di sekitar Simpang Lima Semarang). Diakses dari https://repofeb.undip.ac.id/id/eprint/5527

Sina, I. Y. N., \& Tefa, G. (2019). Kinerja aparatur Dinas Perdagangan Koperasi dan Usaha Kecil Menengah dalam pelestarian tenun ikat di Kabupaten Sikka Provinsi Nusa Tenggara Timur. Jurnal MSDA, 7, (1), 115.

Sukotjo, H., \& Sumanto, R. A. (2010). Analisa marketing mix-7P (Produk, price, promotion, place, partisipant, 
process, dan physical evidence) terhadap keputusan pembelian produk Klinik Kecantikan Teta di Surabaya. Jurnal Mitra Ekonomi dan Manajemen Bisnis, 1 (2), 216-228

Tendean, M. R., Mananeke, L., \& Ferdy, R. (2020). Pengaruh viral marketing, store location dan food quality terhadap keputusan pembelian di Mcdonald's Manado. Jurnal EMBA, 8(1), 146-155. 